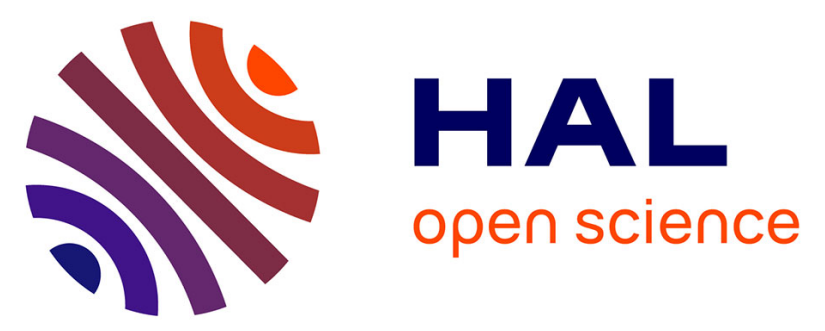

\title{
Everyday vulnerabilities and "social dispositions" in the Malian Sahel, an indication for evaluating future adaptability to water crises?
}

Sylvia Becerra, Mehdi Saqalli, Fabrice Gangneron, Amadou Hamath Dia

\section{- To cite this version:}

Sylvia Becerra, Mehdi Saqalli, Fabrice Gangneron, Amadou Hamath Dia. Everyday vulnerabilities and "social dispositions" in the Malian Sahel, an indication for evaluating future adaptability to water crises?. Regional Environmental Change, 2015, 16 (5), pp.1253-1265. 10.1007/s10113-015-0845-7 . hal-01354112

HAL Id: hal-01354112

https://hal-univ-tlse2.archives-ouvertes.fr/hal-01354112

Submitted on 17 Aug 2016

HAL is a multi-disciplinary open access archive for the deposit and dissemination of scientific research documents, whether they are published or not. The documents may come from teaching and research institutions in France or abroad, or from public or private research centers.
L'archive ouverte pluridisciplinaire HAL, est destinée au dépôt et à la diffusion de documents scientifiques de niveau recherche, publiés ou non, émanant des établissements d'enseignement et de recherche français ou étrangers, des laboratoires publics ou privés. 


\title{
Everyday vulnerabilities and "social dispositions" in the Malian Sahel, an indication for evaluating future adaptability to water crises?
}

\author{
Sylvia Becerra $^{1} \cdot$ Mehdi Saqalli $^{2} \cdot$ Fabrice Gangneron $^{1} \cdot$ Amadou Hamath Dia $^{3}$
}

Received: 19 March 2014/ Accepted: 16 July 2015

(C) Springer-Verlag Berlin Heidelberg 2015

\begin{abstract}
Since the 1970s, precipitation in the Sahel has decreased and become very irregular, leading to widespread drought, whilst the human need for water has rapidly increased. A new "dispositions"-based approach was adapted in order to analyse human interactions with environmental hazards and applied to the case of Hombori village in north-eastern Mali. This article explores how the population and political stakeholders perceive, live with and respond to the increasing scarcity of water. It also explores how their current vulnerability and ability to cope with variations in available water resources indicate future adaptability to climate shocks. On the one hand, this research shows how the population copes with variations in water resource availability: the population's socio-spatial organisation explains the inhabitants' exposure to this problem and some of the factors affecting vulnerability, the elderly and women being the hardest hit. The water issue is generally managed on a "day-to-day" basis and considered
\end{abstract}

Communicated by James D. Ford.

Sylvia Becerra

sylvia.becerra@get.omp.eu

Mehdi Saqalli

mehdi.saqalli@univ-tlse2.fr

Fabrice Gangneron

fabrice.gangneron@get.obs-mip.fr

Amadou Hamath Dia

hamathdia@gmail.com

1 GET (CNRS/IRD/UPS), Observatoire Midi-Pyrénées, 14 avenue Edouard Belin, 31400 Toulouse, France

2 GEODE, CNRS Université de Toulouse II Le Mirail, 5 Allées Antonio Machado, 31058 Toulouse cedex 9, France

3 University of Ziguinchor, Ziguinchor, Senegal a big problem only in the dry season, thus lowering any incentive for self-protection. The main two variables that could explain this kind of risk management are the conflicting local governance and current social rules. On the other hand, the discussion of results, based on a conceptual model of social responses, explains why these current "social dispositions" to cope with and even address the water scarcity issue do not guarantee future adaptability to climate change.

Keywords Water crisis $\cdot$ Vulnerability $\cdot$ Social dispositions $\cdot$ Sahel rural areas $\cdot$ Mali

\section{Introduction}

The scientific consensus on what is now called the "Sahel water crisis" first focused on major changes identified from the late 1960s. The climate in Mali-as elsewhere in the Sahel-has witnessed not only an overall decrease in rainfall but increased irregularity (DNH 2006; ODHD 2005; Mougin et al. 2009; Le Barbé and Lebel 1997; Club du Sahel et de l'Afrique de l'Ouest 2008). This scientific position, centred on climate change and associated hazards, has conveyed for a long time the idea that an external phenomenon is threatening the population, who are rendered if not passive, at the very least incapable of action. This cliché of a passive or vulnerable population is today widely disputed (Wisner et al. 2004; Blaikie et al. 1996; Adger 2003; Bankoff 2003; Thomas 2008; Revet 2009; Brooks et al. 2005; Paavola 2008). Adaptation is a complex process, which takes place at different levels in different ways and has become an essential part of climate research (Simonet and Fatoric 2015). Many uncertainties about future vulnerability, exposure and social responses remain, 
whilst the frequency of droughts may rise dramatically (IPCC 2014).

The fundamental research question addressed herein is whether everyday vulnerabilities and daily strategies for coping with climate variations and the management of seasonal water shortages enable the inhabitants of a rural village to resist and even adapt to potentially worsening water and climatic stresses in the future?

To answer this question, this article proposes first an integrated explanation of the social mechanisms at work in order to have an overview of the way in which people "live with" climate variations. The discussion section analyses the potential link between "ordinary" situations (water shortages; climate variability) and the management of future crises. We challenge the idea that the resilience and adaptability of a population increase when facing risk and environmental change of various types and magnitude. We finally propose a conceptual model of social response linking the intensity of the water shortage, the type of social response to this situation, social vulnerability and "social dispositions".

\section{Theoretical framework}

This analysis is rooted in a dispositions-based approach (Becerra and Peltier 2009; Becerra 2012). In the scientific literature, the French term "disposition" means the individual's cognitive structures-inherited from socialisation and the individual's social trajectory for each specific context and domain-which drive and even determine individual actions. Challenging Bourdieu's theory of "habitus" (Bourdieu 2000), Lahire (2001) develops the "plural actor" theory, which is based on the heterogeneity of socialisation principles and the diversity of social worlds in which the individual's experience and patterns of action are rooted.

The dispositions-based approach we propose here has two special features. First of all, it has been adapted in order to analyse human interactions with environmental hazards and is not therefore restricted to the cognitive aspects or socialisation principles that induce actions: not only are the organisational and social domains included, but their spatiotemporal and political aspects are also taken into account. Playing with the polysemous nature of the word "disposition", the purpose is to answer the question of resources at one's disposal with which one can face short- or long-term environmental change. Indeed, this approach takes into account three "social dispositions":

(i) The socio-spatial organisation influencing the degree of exposure to risks (i.e. water shortages). In the present case study, this refers to the distance to wells and other water resources and the community's organisation to satisfy the need for water. (ii) The willingness or unwillingness of people to think about and reduce risks. In other words, the ways in which one can act or consider matter, given both past experience and the current situation. In the present case study, this refers to the perception of risk, to behaviour and social practices to cope with variations in water resource availability.

(iii) Collective measures taken to resist, recover and/or adapt. In the present case study, this refers to the collective management of water availability and access to prevent or limit the impact of water shortages, for instance.

We consider that the combination of these three types of "social disposition" explains how people "live with" risks, i.e. explains both their degree of social vulnerability to environmental changes and their ability to cope. "Social dispositions" are thus the conditions and resources that enhance or reduce people's social ability to cope with and even address socio-environmental risks; they are necessarily inherited from past situations, prior learning or habits created over time due to recurring experiences; they have sometimes been brought into question in specific conditions, been proven or redefined by events (whether political, environmental, economic or social). However, they both are influenced by current conditions.

Social vulnerability represents in this paper the difficulty in meeting essential needs because of a water shortage: cooking, washing, cleaning, washing up and washing clothes as well as supplying drinking water for animals (Sakdapolrak 2007). The "crisis" concept is restricted to large-scale events such as the major droughts of 1972-74 and 1984-85. The term seasonal shortage is employed for a recurring threat, such as the regular dry season shortages. Resistance evokes an individual or socio-system's capacity to withstand a shortage by reducing its needs (Pelling 2003). Resilience describes the capacity of a system to recover and regain an equivalent "normal" state after disturbance, shock or stress, without an irreversible transformation (Holling 1973) of its structure, identity or function (Walker et al. 2002). This leads to a temporary change in practices until a return to normal is possible. Adaptation defines the adjustments and changes to social systems needed to improve the system's ability to cope with environmental change.

\section{Data and methods}

The study site is the rural village of Hombori in northeastern Mali, one of the rare places in the Gourma area accessible by an asphalt road and offering basic 
accommodation. It was a relevant case for exploring the issue of short-term coping with climate variability versus long-term adaptation to climate shocks because of the scientific knowledge previously acquired by the AMMA project (African Monsoon Multidisciplinary Analysis, www.amma-international.org). The research team demonstrated the influence of variations in the African monsoon and its impact on a decrease in water resources (Mougin et al. 2009) and subsequently in the water available for human consumption. However, scientific knowledge about the social dynamics taking place was needed in order to fully understand the real impact of this "environmental change" in both the short and longer terms.

\section{Hombori, a water issue in the Gourma region}

The village of Hombori, in the foothills of Mount Hombori $(1155 \mathrm{~m})$ in the Gourma region of Mali, is the administrative centre of a similarly named commune including approximately 25 hamlets and 18,000 inhabitants of diverse ethnic origins, such as Songhai, Fulanis, Tuaregs and Dogons. These ethnic groups are further divided into noble castes or former slaves: for example, the Bellahs are the descendants of Tuareg slaves.

The village is organised into two sub-villages separated by the asphalt road leading from Sévaré to Gao (Fig. 1): the old Upper Hombori village (three districts, about 2325 inhabitants) and the more recently built Lower Hombori (four districts, approximately 3850 inhabitants), where political and administrative authorities and economic activities can be found (ANTEA 2005).

Of the various water resources (Gangneron et al. 2010) available in the commune (pools, temporary water courses, cisterns, dams, sumps, traditional and modern wells, human-powered pumps and drinking fountains), the wells and water conveyance system are the main water resource for villagers (Fig. 1). Today, approximately 15 modern and traditional wells in the foothills of Mount Hombori and nine drinking fountains (scattered throughout the village) are used to supply the population.

\section{Field investigation}

The investigation focused on the villages. Due to the lack of reliable data regarding the social aspects of the study area, primary data were collected during four field surveys (January 2007; November 2007; August 2008; and October 2009). Factual data on local water-related history and locally important role players were obtained through interviews with key figures who also facilitated field accessfive interviews with the National Hydraulics Department; one interview with the National Department for Regional Authorities; and two interviews with the two local stateappointed governors-as well as with two Non-Governmental Organisations (NGOs) and two village-based women's associations. The investigation team also conducted 30 qualitative interviews with local families focusing on both their perception of their own vulnerability and their daily practices and water usage strategies according to the season as regards watering livestock, drinking, cooking and washing. The term crisis was not employed during interviews in order to enable participants to employ their own words. Six focus groups were also organised, two consisting of the elderly, two of young men and two of women. In addition, 15 interviews were carried out with elected municipal officials and village chieftainship counsellors. Other data were collected to analyse constraints and limitations with regard to water management: four interviews with Malian social science researchers; two interviews with Hombori representatives of a civil engineering firm in
Fig. 1 General organisation of Hombori village

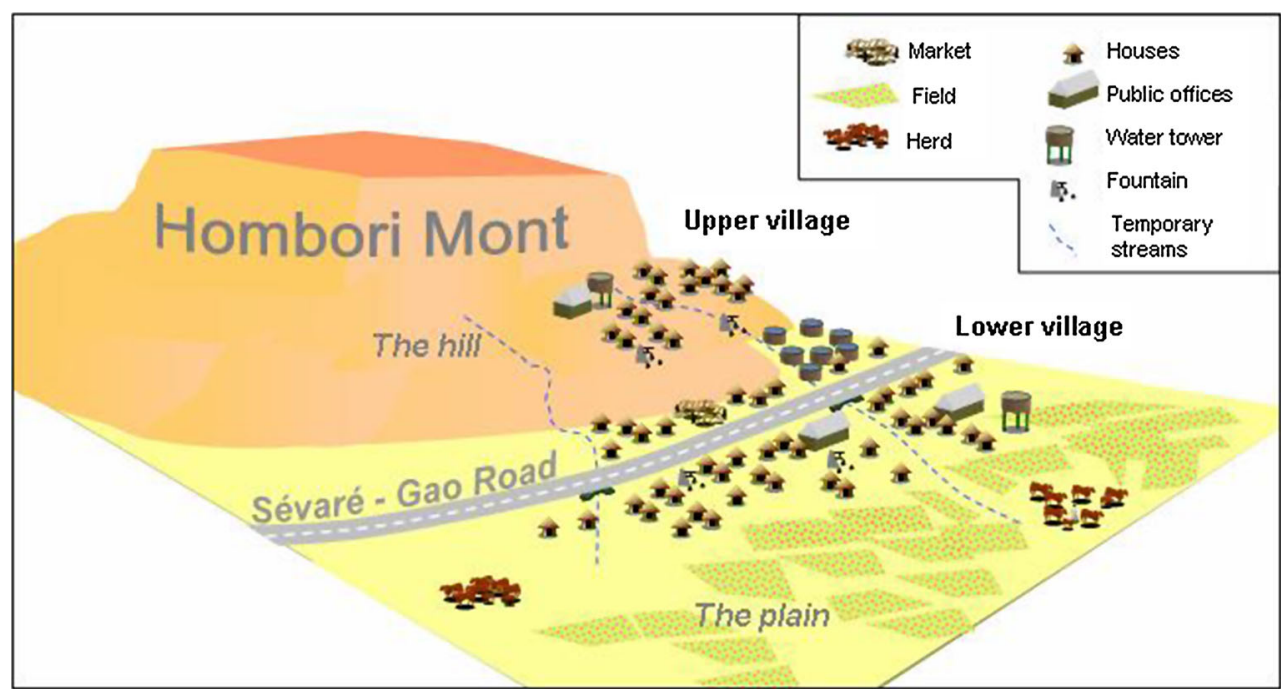


charge of the construction of a new water conveyance system; and finally, consultation of 45 policy and administrative documents from water management ministries. All the collected data were analysed using classical qualitative methods of social research, and in particular content analysis (Bardin 1977). This article presents a synopsis of this data, necessarily selective. Although field investigations were called to a halt following the deterioration of security in Mali in 2011, our contacts in situ have enabled us to monitor the situation, confirming that the findings presented below remain relevant.

\section{Results}

\section{Socio-spatial organisation: unequal exposure and degrees of vulnerability}

In Hombori village and commune, the distribution of water resources is unequal over both space and time (Gangneron et al. 2010). This forces the community to organise themselves to obtain the best possible access to water in the different seasons, however difficult the situation may be. Our observations and knowledge of the history of water supply to Hombori village (Table 1) reveal that inhabitants face unequal exposure to the problems arising from water shortages and that there are different degrees of vulnerability during these shortages.

During the rainy season, from the end of June to midSeptember, many wells whose water is considered of poor quality (tasting bitter or containing suspended matter) are abandoned. They are thus exclusively used as playgrounds for children or for bathing or washing clothes. There is also an increase in the use of ad hoc resources: two streams and many temporary pools are used by the population of Hombori village, mainly for drinking purposes, but only for a maximum of $48 \mathrm{~h}$ after a rainstorm. After this time, these sources dry up completely.

The dry season in Mali, from mid-September to the end of June the following year, has been lengthening, whilst the rainy season has shortened and become less intense since the 1970s (Mougin et al. 2009). The mean rainfall from 1950-1971 was $466 \mathrm{~mm}$, whilst for the period from 1972-2004, rainfall was measured at $324 \mathrm{~mm}$, with higher inter-annual variability (Fig. 2). During this season, most wells run dry and a severe water shortage affects the population, especially from January to the end of June, revealing large inequalities between Upper and Lower Hombori villages at least until the water conveyance system was renovated, with the addition of two deep boreholes.

Indeed, the wells being situated in the lower part of the village, the inhabitants of Upper Hombori are the most vulnerable (Mougin et al. 2009) to water stress. During the dry season, one member of the family is designated as the water collector for $24 \mathrm{~h}$ (day and night) due to the wells' low output. Some people collect water mainly during the night in order to reduce the mundane nature of this task:

In the dry season, we go to the wells at night when the moon lights the path to be back before sunrise. But day after day, the moon rises later, so the time for fetching water shortens (Upper Hombori village woman, interview extract, November 2007).

Fetching water is traditionally the responsibility of a woman: for her, the difficulty of this task varies according to the season, distance to the wells and number of children available to help. For some women from Upper Hombori, particularly weaker or more isolated villagers, obtaining water is even more onerous since they have no choice but to pay water carriers. Nevertheless, in comparison with the situation 20 years ago, women nowadays have economic opportunities such as market gardening or small trade during market days which grant them more independence from their husbands.

Traditionally, young people should bring water to older people. Those who have to collect water for themselves are socially isolated. Their presence at wells is therefore a visible trace of a certain failure of social networks and the values of inter-generational solidarity.

Towards the end of the dry season, water stress has other major effects beyond thirst: cooking requires water; small livestock herds also need water in order to survive. The French word soudure, translated "hunger gap", defines the period between the end of food stocks from the previous harvest and the new harvest (Bidou and Droy 2009). Applying the same concept to water, a "thirst gap" can thus be characterised as the equivalent period of struggle between the wells drying up during the dry season and the first monsoon rains.

The failure of successive water conveyance systems since 1953 (Table 1) demonstrates a lack of organisation in the maintenance and management of local resources and increases social vulnerability to water stress, which is not only a water availability issue, but also a "socially induced" threat.

\section{Perceptions of vulnerability and coping strategies}

Social perceptions are part of the population's "social dispositions" (Becerra and Peltier 2009) to cope with environmental risks. Few studies have been carried out up to now on how African populations perceive their own vulnerability to climate variability and its associated hazards (Tschakert 2007; Janin 2007), even though the role of perception in individual behaviour (Slovic 2002; 
Table 1 History of water conveyance systems in Hombori village (1953-2011)

\begin{tabular}{|c|c|c|c|c|c|}
\hline Date & Type of system & $\begin{array}{l}\text { Position in } \\
\text { Hombori } \\
\text { village }\end{array}$ & Characteristics & Key players & Current condition \\
\hline 1953 & $\begin{array}{l}\text { Initial water } \\
\text { adduction } \\
\text { system }\end{array}$ & $\begin{array}{l}\text { Lower and } \\
\text { Upper } \\
\text { Hombori }\end{array}$ & Water tower & French authorities & \\
\hline 1957 & & $\begin{array}{l}\text { Lower and } \\
\text { Upper } \\
\text { Hombori }\end{array}$ & $\begin{array}{l}\text { A 7-metre-deep well located at the foot } \\
\text { of Mount Hombori } \\
\text { A pump sends water through an } \\
\text { underground pipe } \\
\text { Water tower at the top of Upper } \\
\text { Hombori (gas-fuelled power generator) } \\
\text { Two drinking fountains }\end{array}$ & French authorities & $\begin{array}{l}\text { Broke down in the late } \\
1960 \text { s }\end{array}$ \\
\hline 1983 & $\begin{array}{l}\text { Renovation of } \\
\text { the water } \\
\text { system }\end{array}$ & $\begin{array}{l}\text { Lower and } \\
\text { Upper } \\
\text { Hombori }\end{array}$ & - & - & $\begin{array}{l}\text { Broke down within } \\
2 \text { years }\end{array}$ \\
\hline 1985 & $\begin{array}{c}\text { Borehole in } \\
\text { Kissingui }\end{array}$ & $\begin{array}{l}\text { Kissingui, } \\
10 \mathrm{~km} \text { from } \\
\text { Hombori }\end{array}$ & & $\begin{array}{l}\text { The Malian national } \\
\text { roads directorate } \\
\text { (DNR) }\end{array}$ & $\begin{array}{l}\text { Site too far from the } \\
\text { village }\end{array}$ \\
\hline 1994 & $\begin{array}{l}\text { Renovation of } \\
\text { the water } \\
\text { system }\end{array}$ & $\begin{array}{l}\text { Lower and } \\
\text { Upper } \\
\text { Hombori }\end{array}$ & $\begin{array}{l}\text { Renovation of the water pumping system } \\
\text { and connection to } 21 \text { drinking } \\
\text { fountains }\end{array}$ & $\begin{array}{l}\text { ACMIS, a project } \\
\text { supported by the } \\
\text { German cooperation } \\
\text { service }\end{array}$ & $\begin{array}{l}\text { Broke down after a few } \\
\text { months }\end{array}$ \\
\hline 1999-2000 & $\begin{array}{l}\text { New water } \\
\text { pumping } \\
\text { system }\end{array}$ & $\begin{array}{l}\text { Lower } \\
\text { Hombori }\end{array}$ & $\begin{array}{l}\text { System powered by solar panels. Four } \\
\text { public drinking fountains provide } \\
\text { water from a newly built water tower in } \\
\text { Lower Hombori; Upper Hombori is no } \\
\text { longer connected }\end{array}$ & $\begin{array}{l}\text { ANTEA, an NGO } \\
\text { working with the } \\
\text { national water } \\
\text { programme }\end{array}$ & Broke down in 2007 \\
\hline 2006 & $\begin{array}{l}\text { Renovation of } \\
\text { six wells }\end{array}$ & $\begin{array}{l}\text { Lower } \\
\text { Hombori }\end{array}$ & Six new wells open to all & $\begin{array}{l}\text { A member of a noble } \\
\text { family, currently an } \\
\text { executive in the } \\
\text { German cooperation } \\
\text { service }\end{array}$ & $\begin{array}{l}\text { The system is still } \\
\text { operational, but } \\
\text { several wells run dry } \\
\text { in the dry season }\end{array}$ \\
\hline 2007-2008 & $\begin{array}{l}\text { Water } \\
\text { impoundments }\end{array}$ & $\begin{array}{l}\text { Villages in the } \\
\text { commune } \\
\text { outside } \\
\text { Hombori } \\
\text { village }\end{array}$ & $\begin{array}{l}\text { Cement, tools and a mechanical digger } \\
\text { from the CCNGO/EFA used to build } \\
\text { several impoundments outside } \\
\text { Hombori village }\end{array}$ & $\begin{array}{l}\text { CCNGO/EFA the NGO } \\
\text { programme of } \\
\text { UNESCO in West } \\
\text { Africa }\end{array}$ & $\begin{array}{l}\text { The impoundments are } \\
\text { still operational }\end{array}$ \\
\hline 2007-2008 & Dam & $\begin{array}{l}\text { Lower } \\
\text { Hombori }\end{array}$ & $\begin{array}{l}\text { An impoundment on one of the two } \\
\text { temporary streams }\end{array}$ & $\begin{array}{l}\text { A group of Hombori } \\
\text { natives working in } \\
\text { Bamako }\end{array}$ & $\begin{array}{l}\text { Rapidly destroyed } \\
\text { during the first heavy } \\
\text { rains following } \\
\text { construction }\end{array}$ \\
\hline 2006-2011 & $\begin{array}{l}\text { Renovation of } \\
\text { the water } \\
\text { conveyance } \\
\text { system }\end{array}$ & $\begin{array}{l}\text { Lower and } \\
\text { Upper } \\
\text { Hombori }\end{array}$ & $\begin{array}{l}\text { A borehole in Lower Hombori and a } \\
\text { generator to pump water to drinking } \\
\text { fountains are implemented in both } \\
\text { parts of Hombori thanks to a newly } \\
\text { built second water tower in Upper } \\
\text { Hombori that was connected to Lower } \\
\text { Hombori } \\
\text { A charge is made for access to these } \\
\text { drinking fountains ( } 20 \mathrm{CFAf} / \\
\left.201=1000 \mathrm{CFA} \text { Francs } / \mathrm{m}^{3}\right) \\
90 \text { private connections }\left(550 \mathrm{CFA} / \mathrm{m}^{3}\right)\end{array}$ & $\begin{array}{l}\text { One candidate for } \\
\text { election as mayor } \\
\text { DNH, the Malian Water } \\
\text { Bureau } \\
\text { Local committee }\end{array}$ & $\begin{array}{l}\text { The system remains } \\
\text { operational, but } \\
\text { several fountains } \\
\text { were closed in early } \\
2011 \\
\text { (five are available in } \\
\text { Upper Hombori and } \\
\text { six in the lower } \\
\text { village); } \\
\text { The generator has } \\
\text { broken down on } \\
\text { several occasions } \\
\text { Cause: not enough } \\
\text { money because of } \\
\text { poor management }\end{array}$ \\
\hline
\end{tabular}




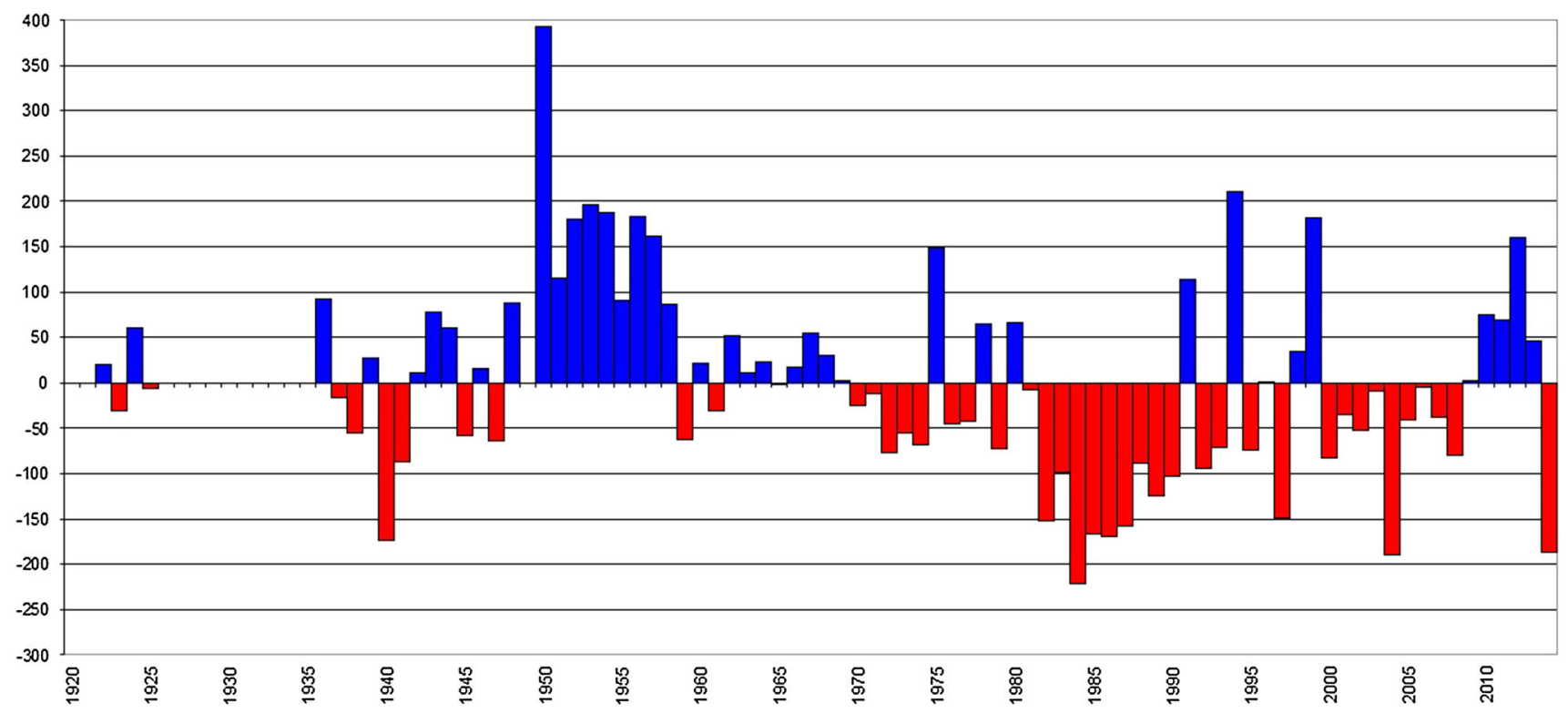

Fig. 2 Annual average rainfall [mm] anomalies in Hombori, 1920-2014 (mean $=375 \mathrm{~mm}$ ), source: DNM/AMMA-CATCH. The 0 value on the $\mathrm{y}$ axis represents the average rainfall value for this period; the anomalies are deviations from this average

Grothmann and Reusswig 2006; Adger et al. 2009), and particularly in adaptation (Grothmann and Patt 2005; Weber 1997; Simonet and Fatoric 2015), has been demonstrated.

Insecure access to water perceived as a familiar, seasonal situation

Structurally speaking, the Sahel rainfall regime is obviously a major limitation to development. The 1972-73 and 1984-85 droughts are periods of social collapse, described by interviewees as the start of the period of severe water shortages in Hombori, continuing to the present time. Many "environmental migrants" (Gonin and Lassailly 2002; Cournil 2006) have moved to Hombori, particularly after the 1984-85 drought episode. A shortage of water is an "everyday vulnerability" that has been present for decades, so the situation is familiar:

We have always experienced water crises; since our childhood, we know that many local villages lack water (A woman from Hombori village, interview extract, November 2007).

In other words, the situation is not considered "critical" the rest of the year, especially during the rainy season, when there is enough water to be found in wells and pools.

However, the feeling of vulnerability is also due to the unreliability of physical water infrastructures: ageing traditional wells can collapse at any time, and new wells are shallow, reducing their durability. There is no programmed maintenance for either these wells or recent water conveyance systems (boreholes, drinking fountains, pipes, etc.), so none is undertaken despite the successive breakdowns of previous systems (see Table 1). Interviewees consider that the main problem is finding water sources that both are durable and have sufficient flow.

Water trade: ethnic minorities' adaptation strategy

During the dry season, Dogon or Bella women trade water: prices vary according to the season, the severity of the seasonal shortage, the location of the customer's house with regard to the wells and even the water's origin (salty or bitter water being cheaper). A 20-L jerrycan of water is sold at an average of 20 CFA Francs $(€ 0.015)$ at the drinking fountain $\left(1000 \mathrm{CFA}\right.$ Francs $/ \mathrm{m}^{3}$, i.e. $\left.€ 0.76 / \mathrm{m}^{3}\right)$. Once the jerrycan has been bought at the fountain, female carriers in Hombori sell it at 50-75 CFA Francs (€0.08$€ 0.11$ ) to houses in Lower Hombori (2500 to $3750 \mathrm{CFA}$ Francs $/ \mathrm{m}^{3}$, i.e. $€ 3.81-€ 5.72 / \mathrm{m}^{3}$ ) and up to 100 CFA Francs $(€ 0.15)$ in Upper Hombori (5000 CFA Francs $/ \mathrm{m}^{3}$, i.e. $\left.€ 7.62 / \mathrm{m}^{3}\right)$. In the dry season, these prices double, i.e. 10,000 CFA Francs $/ \mathrm{m}^{3}$, i.e. $€ 15.24 / \mathrm{m}^{3}$ ), making this water 20-40 times more expensive than tap water in the country's major cities $\left(250 \mathrm{CFA}\right.$ Francs $\left./ \mathrm{m}^{3}\left(€ 0.38 / \mathrm{m}^{3}\right)\right)$. Such costs are a huge part of the average six-person family budget, estimated at about $€ 38$ or 25,000 CFA Francs per month per family. 


\section{Water-sharing norms and conflict management}

In Gourma, it is customary to share water, even in the dry season (Gallais 1975), and especially on market day. The rare owners of private wells in the village exchange access for those in need. The rule is that every individual can collect only one bucket of water in exchange for his/her help:

They leave two filled water buckets in the branches surrounding the well, and then they can fill a bucket for themselves. It is a good deal for everyone (An inhabitant from Lower Hombori, interview extract, November 2007).

At public wells, the rule is: "first come, first served", but also with only one bucket of water per individual. However, when needs increase, meaning more time wasted in queuing and increased fatigue, tensions rise and conflicts break out, forcing the physically or socially weakest (mainly children and the elderly) to give up their place in the queue:

Whilst everyone is waiting their turn, some people turn up and jump the queue to go first. If you are weak or old, then you have no water (Youth focus group, August 2008).

Moreover, water becomes a power struggle between natives and transhumant herders who use the wells designated for human consumption instead of the very deep, wide wells designated for watering their herd, thereby creating increased demand on already limited resources.

\section{"Day-to-day" coping strategies}

During the rainy season, families vary their sources of supply to include wells, rivers and temporary water points. In the dry season, it becomes necessary to reduce water consumption, a resistance practice that gradually develops from a reduction in washing up to a rationing of drinking water. Meals can be cooked alternatively by neighbouring families, so long as each family can provide water and even food. Sometimes none of the families are able to fulfil these criteria. These adjustment practices are related to both the population's extreme poverty and the structural lack of perennial resources, as observed in interviews:

Even if you have money to buy water, or donkeys to carry the jerrycans, you can't fetch water because wells have dried up (An inhabitant from Lower Hombori, extract from interview, November 2007).

The water issue is therefore generally managed on a "day-to-day" basis.

\section{Collective measures to promote adaptation: the weak link?}

"Social dispositions" also refer to the collective measures that regulate, influence, enhance or reduce the community's ability to deal with water shortages and that are taken at the suggestion of either local authorities or the community. Local governance is a key variable in understanding how people perceive and regulate water issues (Becerra and Roussary, 2008).

\section{Local governance: water as a political opportunity}

Studying local governance sheds light on the reasoning of the various actors involved in the water issue and the collective measures they have managed to take. In Hombori, political dynamics turn water into a political opportunity where lineages compete. Access to water becomes access to power. The political situation in Hombori village is in fact a superimposition of two legitimate authorities due to the decentralisation process (Totté et al. 2003; Dia et al. 2008): the municipality, established in 1999, and the traditional chieftainship (Dia et al. 2008). In 1999, the municipality inherited tax-collecting power, therefore transferring the budget power from the chief to the mayor. This situation has created a political arena, an obvious opportunity for other lineages to gain access to power. Whilst the Maïga lineage has so far kept the chieftainship - the traditional political legitimacy-the Hombori municipal council is in the hands of a Garicko-lineage member thanks to the financial support of his brother, a rich trader in Niger. In the electoral system, the next candidates for election-including the mayor-have to negotiate and bargain to form coalitions, even if it means laying aside municipal projects. Access to water thus became one of the main issues of the 2008-2009 municipal campaign:

(i) The mayor promised the rehabilitation of the former conveyance system that broke down in 2007, using the electoral promise of the re-elected national president to bring a durable supply of drinking water to Hombori as a guarantee of the arrival of state public funds. However, the implementation of such a system would have meant paying for such a service.

(ii) The opposing "Maïga" lineage proposed the renovation of several open-access traditional wells in Lower Hombori. The project-cheaper and less complicated-required only private funds and expertise from one prominent member of the Ganaba lineage, a rich expatriate working for the German Cooperation Service with many 
connections in Bamako, the capital of Mali. This rehabilitation project was effective before the elections.

$\mathrm{BaaBe} H u$ is a social norm that explains the difficulty in implementing a lasting solution to water stress. It literally means "the house of the father", in other words loyalty to lineage and social class. By favouring clan loyalty instead of the political project of municipal candidates, $\mathrm{BaaBe} \mathrm{Hu}$ reinforces the role of lineage in local political activity and encourages system inertia. It is therefore not surprising if there is a social lack of trust in the capacity of governing authorities to genuinely deal with the water needs of the population.

\section{Community institutions and social rules: limitations to coping and adapting?}

In this context, the inhabitants of Hombori village have taken some collective initiatives to improve access to water. However, the effectiveness of their actions has been limited by several social rules and by the maintenance of community structures which restrict rather than facilitating action.

Little capacity for collective action Several times during the dry season, the village chief calls on the community to clean and repair wells that have become unusable during the rainy season. He also draws up a schedule of well usage for the different districts of Upper Hombori, where he has official authority. Only once, in 2007-2008, did villagers attempt to build an impoundment project in Lower Hombori, which unfortunately collapsed with the first rains. This failure highlights the poor technical and financial capabilities on a local scale and seems to have discouraged-at least temporarily_any similar initiatives (Table 1).

When questioned on the subject of consolidating access to water, the villagers-regardless of age-insisted on the need for outside financial and technical assistance via fundraising by NGOs or aid from Hombori citizens living in Bamako. They considered themselves as potential players in ensuring water security only when explicitly questioned on their own ability to act. They explained their helplessness by seasonal migration of youth after the harvests, the absence of community decision-making structures, but also the low level of commitment of local authorities. Physical strength and "courage" are thus perceived as the only available assets, but these are limited.

Barriers to youngsters' initiatives Some young bachelors from Hombori village between the ages of 16 and 25 acknowledge that they could provide new ideas on how to combat water shortages or environmental problems in the village, but they had never organised themselves: "water stress" is considered so commonplace they have never even discussed it amongst themselves. Like other groups in the population, they have adopted a wait-and-see attitude, hoping for outside help. The $\mathrm{BaaBe} \mathrm{Hu}$ rule enforces their powerlessness and limits their proactivity regarding water management, as only the elderly are privileged enough to have discussions and make decisions. Bypassing this rule would imply a dialogue between younger and older villagers, which would require a radical change of mentality and consequent redistribution of power that the young interviewees do not know how to cope with.

\section{Discussion: from ordinary vulnerabilities to future adaptability}

The hypothesis supported by Walker et al. (2002) states that the resilience and adaptability of a population can increase when facing risks and environmental change events of various types and magnitude. We challenge this postulate.

\section{Uncertainties on future adaptability}

Table 2 presents a modified version of the classification by Burton et al. (2006) concerning a typology of actions people undertake when faced with a climatic shock. It is organised on three levels: family, community and political actions. "Regulatory" actions have been added to Burton's typology to designate operational short-term measures undertaken regularly (during the dry season) in order to maintain access to resources. They include, for example, annual well maintenance but do not fundamentally modify the social organisation.

Table 2 also identifies eight vulnerability factors that explain the identified actions (1) poor management of water infrastructures (wells, water conveyance systems, pumps, etc.), (2) zero capacity for family buffers (water storage), (3) social perception of this vulnerability as normal, (4) little social control, (5) a "captive" civil society, where rights and capacity for action vary according to position in the social hierarchy, (6) appropriation of the water issue for political reasons, in this case electoral purposes, (7) dependence on outside aid limiting local initiatives, (8) unequal spatiotemporal distribution of water resources.

The first three factors are clearly linked to poverty. The following four could be linked to the concentration of power by an oligarchic system. The last factor is based on structural data on the studied site.

How then do these vulnerabilities affect the population's ability to adapt in the future? 
Table 2 Social responses observed in Hombori village (2007-2009)

\begin{tabular}{|c|c|c|c|}
\hline & Individual and family level & Community level & Local political authority level \\
\hline $\begin{array}{l}\text { Resistance } \\
\text { ("reactive } \\
\text { actions" in } \\
\text { Burton, 2006) }\end{array}$ & $\begin{array}{l}\text { Rationing of consumption } \\
\text { For some, mobilisation of other resources } \\
\text { (work or money) }\end{array}$ & $\begin{array}{l}\text { "Strongest wins"; } \\
\text { "First come, first served" }\end{array}$ & $\begin{array}{l}\text { In the event of a severe drought, the } \\
\text { State and NGOs are alerted }\end{array}$ \\
\hline $\begin{array}{l}\text { Vulnerability } \\
\text { factors that } \\
\text { explain } \\
\text { observed } \\
\text { responses }\end{array}$ & $\begin{array}{l}\text { (1) Little availability of labour for coping } \\
\text { with inflexible needs (drinking water, } \\
\text { water for cooking) } \\
\text { (2) Economic poverty and social isolation } \\
\text { (3) Water scarcity perceived as normal: a } \\
\text { destiny unable to be changed } \\
\text { (8) Rubbish discarded in the wells and } \\
\text { distance to houses }\end{array}$ & $\begin{array}{l}\text { (4) Little social control over vital } \\
\text { water situations } \\
\text { (8) Rubbish discarded in the wells } \\
\text { and distance of resources with } \\
\text { regard to houses }\end{array}$ & $\begin{array}{l}\text { (7) Highly dependent on outside aid as } \\
\text { little ability to conceive solutions on a } \\
\text { local scale }\end{array}$ \\
\hline Regulation & None at this level & $\begin{array}{l}\text { The "charitable" version of local } \\
\text { social norms: "one cannot refuse } \\
\text { water to those who ask"; } \\
\text { Rehabilitation of wells each year } \\
\text { during the dry season }\end{array}$ & $\begin{array}{l}\text { Restoration project for wells situated on } \\
\text { the foothills ("the Maïga candidate's } \\
\text { project") }\end{array}$ \\
\hline $\begin{array}{l}\text { Vulnerability } \\
\text { factors that } \\
\text { explain } \\
\text { observed } \\
\text { responses }\end{array}$ & $\begin{array}{l}\text { (1) Lack of materials, such as jerrycans, } \\
\text { carts or donkeys for transporting and } \\
\text { storing water; } \\
\text { (8) Insufficient availability and } \\
\text { accessibility of water with regard to } \\
\text { needs }\end{array}$ & $\begin{array}{l}\text { (5) Social norms enabling control } \\
\text { over access to water are fragile } \\
\text { because regularly flouted during } \\
\text { water crises }\end{array}$ & $\begin{array}{l}\text { (3) Few elected members evoke the } \\
\text { water issue as a major problem; } \\
\text { (6) The absence of institutions for } \\
\text { managing infrastructures: no } \\
\text { awareness of the municipal council nor } \\
\text { budget dedicated to system } \\
\text { maintenance }\end{array}$ \\
\hline $\begin{array}{c}\text { Proactive } \\
\text { actions }\end{array}$ & Rare & $\begin{array}{l}\text { Failed attempts: } \\
\text { A storage dam for runoff water: } \\
\text { even if this failed, the project } \\
\text { remains a community action } \\
\text { Project on the Kissingui borehole } \\
\text { water (rejected by Nat. } \\
\text { Hydraulics Department) }\end{array}$ & $\begin{array}{l}\text { Rehabilitation of the water conveyance } \\
\text { system with maintenance tax ("the } \\
\text { mayor's project") }\end{array}$ \\
\hline $\begin{array}{l}\text { Vulnerability } \\
\text { factors that } \\
\text { explain } \\
\text { observed } \\
\text { responses }\end{array}$ & $\begin{array}{l}\text { (1) Lack of resources (one out of } 30 \\
\text { families has a storage reservoir) and/or } \\
\text { family wells } \\
\text { (3) The water issue is only considered } \\
\text { serious at the end of the dry season: the } \\
\text { rest of the year, the situation is not } \\
\text { perceived as critical }\end{array}$ & $\begin{array}{l}\text { (1) Technical skills and limited } \\
\text { funds for undertaking efficient } \\
\text { actions } \\
\text { (3) Kissingui seen as a water "El } \\
\text { Dorado": solutions can only } \\
\text { come from outside the village } \\
\text { (7) A dependency attitude towards } \\
\text { external development actors } \\
\text { (5) Limits linked to social norms: } \\
\text { age, gender and local oligarchies } \\
\text { limit access to debates }\end{array}$ & $\begin{array}{l}\text { (3) Lack of perception of coming climate } \\
\text { change, including climatic hazards, at } \\
\text { least equal to 20th century droughts } \\
\text { (6) Electoral competition between } \\
\text { lineages leads to an irregular } \\
\text { commitment of the elected members } \\
\text { regarding the water issue: the } \\
\text { municipal council has no projects for a } \\
\text { durable and well-maintained water } \\
\text { supply system }\end{array}$ \\
\hline
\end{tabular}

Despite a wealth of experience in water shortages, the future adaptability of Hombori villagers and local political actors is very uncertain for various reasons. First, some social systems are able to manage climate variability and natural resources, but are not yet resistant to climate change (Walker and Salt 2006). In Hombori, people's everyday experience of risk is limited to a given magnitude of events, and nothing guarantees that this experience can be transposed to extreme situations. Moreover, those with no experience will be unprepared (Becerra et al. 2013).
Secondly, the attitude of villagers may act as a "limiting factor" for adaptation (Adger et al. 2009): they do not actually believe that regular water scarcity may worsen in the future and consider water scarcity just as part of daily insecurity. Thirdly, Hombori's local governance limits resilience when coping with seasonal water shortages, as demonstrated above. The social context (social norms, poverty and community inertia) on the one hand and the overlap and competition between lineages on the other do not facilitate the emergence of self-organisation and 
innovation that could improve the everyday life of the population and a fortiori its resilience to extreme events. Thus, reinforcing resilience on a local scale (Walker et al. 2002) depends on the awareness of operations and practices on both an individual and a family level, but also on support being given by political authorities on a supra-local government scale. The process should therefore be placed in the context of a multi-level governance system.

\section{From normal threats to extreme events: a social response model}

Another question is: Does experiencing normal climate variations improve the population's preparedness for more severe climate shocks or increase ordinary vulnerabilities? Other research (Becerra et al. 2013) has demonstrated that the characteristics of the environmental hazard in question influence the social perception of risk, and consequently the drive for self-protection, increasing social vulnerability to major events. The Hombori case could be considered a prime example of situations of this kind, being subject to not only "normal" threats, but also potentially "extraordinary" events.

The purpose of Fig. 3 is to present a conceptual model of the relationship between the intensity of an event (in this case water scarcity), the social responses to this situation (resistance, regulation, proactive actions and social collapse) and the social vulnerability of individuals or collective entities (the village or family). This graph does not include the time dimension. We fully recognise that this is therefore a simplification of social reality. This relationship should be understood within the context of a socio-ecological system (Walker and Salt 2006; Décamps 2007).

The $X$-axis represents the magnitude of the event and the $Y$-axis the degree of social vulnerability. Linear functions of type $y=a x$ represent different trajectories of individuals or groups when faced with a crisis, depending on the type of event and their own capacity to respond. Slope $a$ depends on factors that may harm or support their response to crisis, such as the "social dispositions" exposed above. Collective action should be considered an

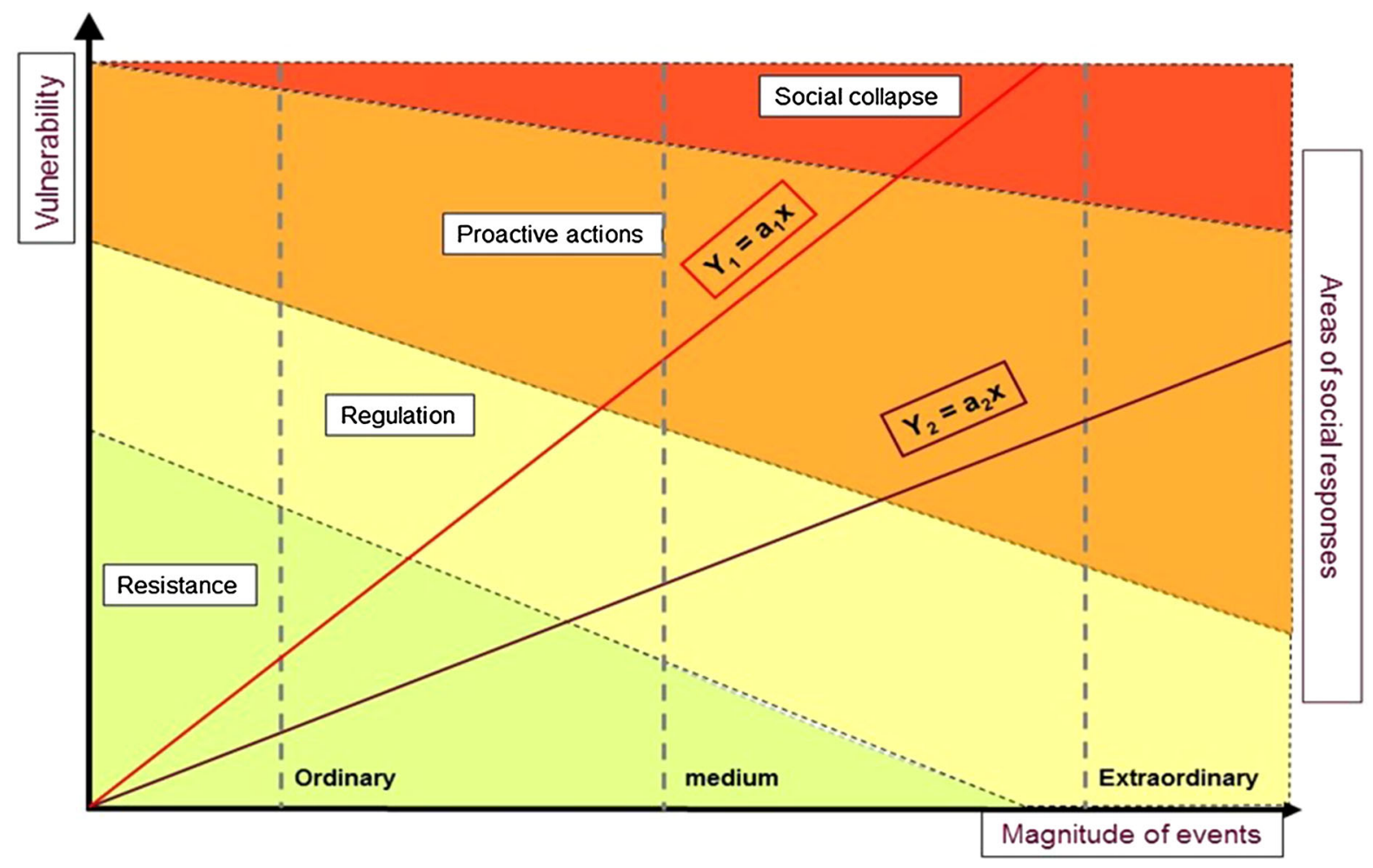

Fig. 3 From normal threats to extreme events: a social response model. Resistence: practices or strategies used to mitigate the impact of expected events on a case-by-case basis. The first strategy is to reduce consumption. Regulation: measures taken regularly to maintain access to resources, e.g. the annual maintenance of wells. Proactive actions: measures to reduce exposure to future events and their potential long-term consequences. A new water conveyance system, for example, would increase the population's access water. Social collapse: a drastic drop in human population (Diamond 2005), such as an environmental migration. $Y_{1}$ a village, family or individual particularly vulnerable to the magnitude of events; $a_{1}$ represents an estimation of the social dispositions employed that enable the village, family or individual to cope; the steep slope of this equation means that the stage of collapse is reached quickly. $Y_{2}$ a village, family or individual less vulnerable to the magnitude of events taking into account the social dispositions employed; $a_{2}$ the gradient of this equation's slope is not as steep 
input to the $Y$ function, as a way of increasing the ability of a family or an individual to address and/or cope with commonplace and familiar shortages, as well as potentially influencing their response to extreme events. The steeper the slope, the more vulnerable the related family/individual. The different colours represent the social responses to crisis: resistance, regulation, adaptation (proactive actions) or social collapse. The straight grey lines represent the projection of an event upon a social trajectory.

This conceptual framework is therefore the qualitative formalisation of the various situations the research team has observed in the field: it does not objectively answer the research question, but rather constitutes a tool with which to formulate possible scenarios for the future based on the processes already observed. Using it as a framework for analysis, this model could therefore provide support for decision-makers. Each change-whether a political empowerment, a new social occurrence or technical innovation for instance-may be translated through the diagram into its impact on the slope gradients of the various types of entities we have considered (comparison between villages or between families in the same village, etc.), thereby creating a new diagram. The utility of such a framework lies in its use in comparative analysis between various situations according to ("Changes in social response according to event intensity" section) event intensity, ("Responses differ between individuals and families" section) types of entity (family/individuals), ("Effect of past events on present or future responses" section) effects of past events or ("Effect of collective measures and institutions" section) changes in collective measures, as shown in the following forward-looking analysis.

\section{Changes in social response according to event intensity}

There is clearly a relationship between the magnitude of the event and the villagers' type of response: faced with a common or regular crisis, regular resistance practices are implemented. If the magnitude of the crisis increases such that it becomes an extraordinary event, resilience practices are adopted. With respect to time, this means a possible return to the previous "ordinary" situation. Under particular circumstances, extreme events may have irreversible consequences on the environment and lifestyle of many families and individuals. Over time, this means a shift to a new "ordinary" situation in which these families and/or individuals can no longer survive (Walker and Salt 2006) depending on both their "social dispositions" for overcoming the difficulty, and the level of risk forecast or the warning of a climatic event (in the graph: dramatic change in the slope gradient indicating a threshold beyond which the social system collapses).
Responses differ between individuals and families

The threshold of a crisis is different for everyone depending on the magnitude of the event, level of social vulnerability and various circumstances affecting an individual or family. Social response is therefore always relative, meaning that the shift from a commonplace crisis, i.e. a known, previously experienced situation, to crises of unknown dimensions is different for every family or individual. For example, a trader could conceivably follow a trajectory with a decreasing gradient because of the profit that could be made from the crisis through speculation.

\section{Effect of past events on present or future responses}

Villagers' responses also depend upon their experience of previous events, as shown by Gaillard (2006) in other case studies. Several hypotheses are possible: the harsher the past event, the lower the villager's capacity to respond, having been forced to progressively sell livestock, for example. However, past events can, on the contrary, also reinforce villagers' resilience when faced with events of a similar level thanks to the experience acquired in terms of understanding the risk and perceiving the need to develop an appropriate preventive response.

\section{Effect of collective measures and institutions}

As we have seen in Hombori, social norms and fragile local institutions with a weak empowerment capacity have an impact on the collective measures taken. Considering that the community's resilience to climate events can be improved or reduced by the type of collective management applied to natural resources (Walker et al. 2002), the diagram indicates that building an expensive, privately funded water system may dramatically decrease the slope gradients for those, and only those, who can afford it. On the other hand, building a public water supply system funded by taxation may decrease slope gradients less, but affect more of the population.

\section{Conclusions}

As in many other regions of the Sahel, the decrease in access to water in Mali's Gourma region is structural. The demographically expanding societies that live in Gourma, dependent on water availability, have often suffered very severe droughts throughout history (Gado 1993) and regularly experience water restrictions. They now need to adapt to a much bigger stress on what are already rare resources. Studies of Hombori "social dispositions" have provided data regarding the population's vulnerability to 
water shortages and their uncertain ability to cope with variations in water supply and a fortiori potentially harsher future climatic shocks:

Due to unequal access to water over space and time: the topographical location combined with water availability and access together constitutes vulnerability factors for the village of Hombori. Isolation and social discrimination based on wealth, gender or age are factors that induce fragility and limit people's capacity to cope, as other research (Becerra et al. 2015) has underlined.

Due to social perceptions and water management practices: the local population considers water scarcity to be a seasonal problem without a lasting solution. In a generalised context of local poverty, vulnerability related to water is thus perceived as an integral part of the daily difficulties experienced throughout the year, with severity varying from one year to the next. As a consequence, the most commonly observed local adaptation strategy when faced with this scarcity is resistance, i.e. reducing consumption. Current coping practices are for the best part individual.

Due to the social and political context: several water conveyance systems have succeeded one another, highlighting by their successive failures the absence of a correctly managed maintenance system that could be sustainably maintained. Recent decentralisation has provided an opportunity for local autonomy. However, local authorities seem incapable of developing the social infrastructure necessary to maintain the physical infrastructure needed for a sustainable water supply. It is also necessary to take into account competition between local authorities and social norms (like clan loyalty or older people's power of decision), for this restricts the collective development of regulatory or proactive measures which are the sole way they can address future climate shocks.

How has the situation evolved since the last investigations in 2009 (i.e. before the commissioning of the water conveyance system in Upper and Lower Hombori)? Access to wells has been facilitated during the dry season by the commissioning of deep boreholes (water conveyance system) which have reduced the time spent queuing for water. Water from boreholes is mainly used for domestic tasks, whilst drinking water is preferably drawn from the wells. This choice is explained by the taste. Neither the cost nor health risks are taken into consideration when making this choice, even though these are factors that exacerbate vulnerability. Furthermore, the water conveyance system's technical failures remain, highlighting the persistent lack of organisation within this community.

How does this study relate to the "big picture?" First, some results have a broader application and are still pertinent even though the fieldwork is dated. These include the impact of structural phenomena such as social norms and local political conflicts on proactive action to face climatic events. Second, the findings from the Hombori case study may be transposed to many similar situations in the Sahel region. Moreover, the "social dispositions" approach is a conceptual model that can be applied to all kinds of environmental risks in any location. Finally, this article highlights the need to reinforce the socio-political and organisational background for a sustainable water supply system. Whilst this seems to be mainly a question of confidence between local players-the chieftainship, municipal council and the mayor-and citizens, the catastrophic increase in civil turmoil (at both local and regional levels) jeopardises all future development work to promote a sustainable water supply.

Acknowledgments This work was performed within the framework of two projects: 1-the African Monsoon Multidisciplinary Analyses project (AMMA), funded by a number of agencies from France, the UK, the US and Africa, with a major financial contribution from the European Union Sixth Framework Research Programme (http://www. amma-eu.org/), and 2-The Elevage CLImat Société (ECLIS) project, funded by the French National Research Agency (ANR).

\section{References}

Adger WN (2003) Social capital, collective action and adaptation to climate change. Econ geogr 79(4):387-404

Adger N, Dessai S, Goulden M, Hulme M, Lorenzoni I, Nelson RD, Otto Naes L, Wolfand J, Wreford A (2009) Are there limits to adaptation to climate change? Clim Change 93:335-354

ANTEA (2005) Etude de faisabilité d'un programme d'hydraulique semi-urbaine dans la région de Mopti. Rapport de fin de phase 1: sélection des centres à équiper. ANTEA, Bamako

Bankoff G (2003) Cultures of disaster: society and natural hazard in the Philippines. Routledge, London

Bardin L (1977) L'analyse de contenu. Presses Universitaires de France, Paris

Becerra S (2012) Vulnérabilité, risques et environnement: l'itinéraire chaotique d'un paradigme sociologique contemporain. VertigO $12: 1$

Becerra S, Peltier A (2009) Risques et environnement: recherches interdisciplinaires sur la vulnérabilité des sociétés. L'Harmattan, Paris

Becerra S, Roussary A (2008) Gérer la vulnérabilité de l'eau potable: une action publique désengagée? Nat Sci Soc 16:220-231

Becerra S, Peltier A, Antoine JM, Labat D, Chorda J, Ribolzi O, Merlet N, Daupras F, Dartus D (2013) Comprendre les comportements face à un risque d'inondation modéré. Etude de cas dans le périurbain toulousain (Sud-Ouest de la France). Hydrol Sci J 58(5):945-965

Becerra S, Ghorbel M, Munoz M, Sappin-Didier V, Kolsi-Bensina N, Touati N, Mouri H (2015) "Comprendre la vulnérabilité sociale aux contaminations minières en Tunisie: exposition chronique et construction sociale des risques sanitaires » In: Béringuier P, Blot F, Desailly B, Saqalli M (ed) Environnement, politiques publiques et pratiques locales. L'Harmattan, Paris, France.

Bidou J-E, Droy I (2009) Décrire la construction temporelle des vulnérabilités: Observatoires ruraux et analyse historique des moyens d'existence dans le sud malgache. In: Becerra S, Peltier A (eds) Risques et environnement: recherches interdisciplinaires sur la vulnérabilité des sociétés. L'Harmattan, Paris, pp 155-170 
Blaikie P, Cannon T, Davis I, Wisner B (1996) Vulnerabilidad. El entorno social, politico y económico de los desastres. Primera Edición, La RED. http://www.desenredando.org

Bourdieu P (2000) Les Structures sociales de l'économie. Seuil, Paris

Brooks N, Adger NW, Kelly MP (2005) The determinants of vulnerability and adaptive capacity at the national level and the implications for adaptation. Glob Environ Change 15:151-163

Burton I, Diringer E, Smith J (2006) Adaptation to climate change: International policy options. Pew Center on Global Climate Change, Arlington

Club du Sahel et de l'Afrique de l'Ouest (2008) Climat, changements climatiques et pratiques agro-pastorales en zone sahélienne. club du Sahel et de l'Afrique de l'Ouest/organisation de coopération et de développement economiques- comité inter-états de lutte contre la sécheresse au Sahel CILSS-Food and Agriculture Organization, Rome, Italy

Cournil C (2006) Vers une reconnaissance du réfugié écologique? Quelle(s) protections, Quel(s) statut(s)? Revue du Droit Public 4:1035-1066

Décamps H (2007) La vulnérabilité des systèmes socio-écologiques aux événements extrêmes: exposition, sensibilité, résilience. Nat Sci Soc 15:48-52

Dia AH, Becerra S, Gangneron F (2008) Crises climatiques, ruptures politiques et transformation de l'action publique environnementale au Mali. VertigO 8:1

Diamond J (2005) Collapse: how societies chose to fail or succeed. Viking, New York

Direction Nationale de l'Hydraulique du Mali (DNH) (2006) Rapport national sur la mise en valeur des ressources en eau: Mali. Etude préparée par le WWAP pour le deuxième rapport mondial des Nations Unies sur la mise en valeur des ressources en eau: l'eau une responsabilité partagée. Version finale, Bamako

Gado BA (1993) Une histoire des famines au Sahel: étude des grandes crises alimentaires (19ème-20ème siècle). L'Harmattan, Paris

Gaillard JC (2006) La culture comme enjeu majeur de la gestion des catastrophes liées à des phénomènes naturels au sein des sociétés traditionnelles. Géorisques 1:43-53

Gallais J (1975) Pasteurs et paysans du Gourma. La condition sahélienne, Centre National de la Recherche Scientifique

Gangneron F, Becerra S, Dia AH (2010) L'étonnante diversité des ressources en eau à Hombori: entre contrastes environnementaux, pratiques locales et technologies extérieures. Revue Tiers Monde 204:109-128

Gonin P, Lassailly-Jacob V (2002) Les réfugiés de l'environnement: une nouvelle catégorie de migrants forcés? Revue européenne des migrations internationales 18(2):139-160

Grothmann T, Patt A (2005) Adaptive capacity and human cognition: the process of individual adaptation to climate change. Glob Environ Change 15:199-213

Grothmann T, Reusswig F (2006) People at risk of flooding: why some residents take precautionary action while others do not. Nat Hazards 38:101-120

Holling CS (1973) Resilience and stability of ecological systems. Annu Rev Ecol Syst 4:1-23

IPCC (2014) Summary for policymakers. In: Climate change: impacts adaptation and vulnerability. Part A: global and sectoral aspects. Contribution ok working group II to the fifth assessment report of the IPCC. Field, C.B., V.R. Barros, D.J. Dokken, K.J. Mach, M.D. Mastrandrea, T.E. Bilir, M. Chatterjee, K.L. Ebi, Y.O. Estrada, R.C. Genova, B. Girma, E.S. Kissel, A.N. Levy, S. MacCracken, P.R. Mastrandrea, and L.L. White (Eds.), Cambridge University press, Cambridge United Kingdom and New York, N.Y., USA, pp 1-32

Janin P (2007) Marginalité, vulnérabilité et pratiques de survie en période de soudure alimentaire. In Proceedings of the Colloque
Dynamiques de pauvretés et vulnérabilités, Louvain-la-Neuve (Belgium)

Lahire B (2001) L'homme pluriel. Les ressorts de l'action, (Nathan, 1998 réédité en poche). A. Colin/Nathan, collection Pluriel, Paris, p 392

Le Barbé L, Lebel T (1997) Rainfall climatology of the HAPEXSahel region during the years 1950-1990. J Hydrol 188-189:43-73

Mougin E, Hiernaux P, Kergoat L, Grippa M, de Rosnay P, Timouk F, Le Dantec V, Demarez V, Lavenu F, Arjounin M, Lebel T, Soumaguel S, Ceschia E, Mougenot B, Baup F, Frappart F, Frison PL, Gardelle J, Gruhier C, Jarlan L, Mangiarotti S, Sanou B, Tracol Y, Guichard F, Trichon V, Diarra L, Soumaré A, Koité M, Dembélé F, Lloyd C, Hanan NP, Damesin C, Delon C, Serça D, Galy-Lacaux C, Seghieri J, Becerra S, Dia AH, Gangneron F, Mazzega P (2009) The AMMA CATCH Gourma Observatory site in Mali: relating climatic variations to changes in vegetation, surface hydrology, fluxes and natural resources. J Hydrol 375(1-2):14-33

Observatoire du Développement Humain Durable (ODHD) (2005) Rapport sur le développement humain au Mali: gestion de l'environnement pour un développement humain durable. United Nations Development Program, New York

Paavola J (2008) Livelihoods, vulnerability and adaptation to climate change in Morogoro, Tanzania. Environ Sci Policy 11:642-654

Pelling M (2003) The vulnerability of cities. Natural disasters and social resilience. Earthscan Publications, London

Revet S (2009) De la vulnérabilité aux vulnérables: approche critique d'une notion performative. In: Becerra S, Peltier A (eds) Risques et environnement: recherches interdisciplinaires sur la vulnérabilité des sociétés. L'Harmattan, Paris, pp 89-99

Sakdapolrak P (2007) Water related health risk, social vulnerability and Pierre Bourdieu in Warner K. perspectives on social vulnerability, Publication Series of UNU-EHS 50-60

Simonet G. and S. Fatoric (2015) Does "adaptation to climate change" mean resignation or opportunity? Regional environmental change, published online: http://link.springer.com/article/ 10.1007/s10113-015-0792-3/fulltext.html

Slovic P (2002). Perception of risk posed by extreme events. Discussion at the conference "risk management strategies in an uncertain world. Palisades, New York, April 12-13

Thomas H (2008) Vulnérabilité, fragilité, précarité, résilience etc. De l'usage et de la traduction de notions éponges en sciences de l'homme et de la vie. TERRA-Ed., collection Esquisses [online] http://terra.rezo.net/article697.html

Totté M, Dahou T, Billaz R (2003) La décentralisation en Afrique de l'Ouest, entre politique et développement. Editions Karthala, Paris

Tschakert P (2007) Views from vulnerable: understanding climatic and other stressors in the Sahel. Glob Environ Change 17:381-396

Walker B, Carpenter S, Anderies J, Abel N, Cumming G, Janssen M, Lebel L, Norberg J, Peterson GD, Pritchard R (2002) Resilience management in social-ecological systems: a working hypothesis for a participatory approach. Conserv Ecol 6 (1):14. [online] http://www.consecol.org/vol6/iss1/art14

Walker BH, Salt D (2006) Resilience thinking: sustaining ecosystems and people in a changing world. Island Press, Washington

Weber EU (1997) Perception and expectation of climate change: precondition for economic and technological adaptation. In: Bazerman MH, Messick DM, Tenbrunsel A, Wade-Benzoni K (eds) Psychological perspectives to environmental and ethical issues in management. Jossey-Bass, San Francisco, pp 314-341

Wisner B, Blaikie P, Cannon T, Davis I (2004) At risk: natural hazards, people's vulnerability and disasters, 2nd edn. Routledge, New York 